\title{
COASTAL NEWCOMER ON MOTORWAYS: THE INVASION OF PLANTAGO CORONOPUS IN HUNGARY
}

\author{
Dávid SCHMidT ${ }^{1}$, Zuzana Dítětová ${ }^{2,}$ Adrienn Horvát ${ }^{3}$ and Péter SzüCs ${ }^{4}$ \\ ${ }^{1}$ Institute of Botany and Nature Conservation, University of West Hungary, \\ H-9400 Sopron, Bajcsy-Zsilinszky u. 4, Hungary; schmidt.david@nyme.hu \\ ${ }^{2}$ Institute of Botany, Slovak Academy of Sciences, Dúbravská cesta 9, 84523 Bratislava, Slovakia \\ ${ }^{3}$ Institute of Environmental and Earth Sciences, University of West Hungary, \\ H-9400 Sopron, Bajcsy-Zsilinszky u. 4, Hungary \\ ${ }^{4}$ Department of Botany and Ecology, Eszterházy Károly College, \\ H-3300 Eger, Lányka u. 6, Hungary
}

Schmidt, D., Dítětová, Z., Horváth, A. \& Szűcs, P. (2016): Coastal newcomer on motorways: the invasion of Plantago coronopus in Hungary. - Studia bot. hung. 47(2): 319-334.

\begin{abstract}
Our study presents Plantago coronopus, a new species of the Hungarian alien flora. We describe its taxonomical and morphological peculiarities, ecological and coenological background of its introduction and naturalisation, and its current distribution in the country. This Eurasian coastal species has greatly accelerated in the early 1990s and today it has reached several countries of Central Europe. In Hungary it was firstly observed in 2013 on numerous sites along the M1 motorway around Györ. One site was reported in Zala County and in the following years in other counties of western Hungary. Recently, it has reached the eastern and northeastern parts of the country also. Its remarkable spread is due to the rapid development of motorway network where specific environmental conditions (e.g. road salting) promote its naturalisation.
\end{abstract}

Key words: invasion, road salting, salt-tolerant plants

\section{INTRODUCTION}

A notable expansion of Plantago coronopus L. and other salt-tolerant coastal species to inland parts of Western Europe has been observed mainly from the last third of the 20th century (e.g. RAABE 1990, ZANGE 1994). Roads are known for being corridors for migration of halophytic plants worldwide (SCOTT and DAvison 1985, PAR BAILleul et al. 2006). In Central Europe, for instance in Germany and Austria the "motorway flora" exceeds 20 coastal herbaceous species (Hohla and Melzer 2003, Hohla and RaAbe 2012). Published data on halophytes occurring on roadsides in other countries of Central Europe are scarce, but in the Czech Republic, at least 16 wild growing salt-tolerant species were detected along various types of roads (ŠERÁ 2010), most frequently Spergularia salina (CHocholouš KovÁ 2013). 
Regarding Hungary, recent casual occurrences of native halophytes on roadsides were reported like Plantago maritima (BARINA 2007) or Limonium gmelinii subsp. hungaricum (BAUER 2015) and new adventive species as well, like Sporobolus vaginiflorus (KIRÁLY and HOHLA 2015) and Cochlearia danica (MolnáR and LöKI 2016).

About Plantago coronopus there is only one remark to its distribution in Hungary given by Soó (1968): Formerly in Rákos (?) settlement ("Egykor a Rákoson (?)"). The data originates from a flora study of Budapest by FILARSZKY (1894) in which the author reports species also from intentional seed sowing (included Plantago coronopus). Therefore its recent localities are new discovery to the Hungarian adventive flora.

\section{MATERIALS AND METHODS}

The study area

The field study was conducted from 2013 to 2016. After the first detection of the species in Györ we have conducted targeted surveys along motorways M1 and M7 and on other main roads of Transdanubia. In the case of motorways the easily accessible places were studied, like rest areas and exits. At the observed sites we recorded the population sizes and ecological circumstances of the species.

Detailed list with raw data of recently known localities is given, moreover quadrant numbers (according to the Central European Flora Mapping System, NIKLFELD 1971) and topographical classification of Hungary is considered (according to DövÉNYi 2010). Nomenclature of flowering plants follows KIRÁLY (2009). For determining the coenological affinities of $P$. coronopus, 12 phytocoenological relevés were recorded according to BRAUN-BLANQUET (1928), estimating plant covers in percent (Appendix 1). Relevés were chosen subjectively in plots dominated by $P$. coronopus. Due to space limitation of the micro-pattern of the species each relevé area is $1 \times 4 \mathrm{~m}$.

For the examination of soil properties of $P$. coronopus, we collected five soil samples from two sites with its highest dominance near Győr. Soil samples were collected from the root-zone without the top-layer of the soil. Metadata of samples and sampling sites (e.g. GPS coordinates, elevation above sea level, date of collection) and the visible soil characters (Munsell-colour, structure, compactness, etc.) were recorded on the spot. After drying the samples, the following soil properties were measured in laboratory: skeletal percent, soil $\mathrm{pH}$ and salinity (potentiometrically), $\mathrm{CaCO}_{3}$ content (Scheibler calcimeter), texture/particle size distribution (MSZ-08-0205 1978, SteFAnOvits et al. 1999) and humus content (FAO 1990). 
The study species

Plantago coronopus L. was described by Linnaeus in 1753. A number of described taxa are treated together in P. coronopus group, which can easily be recognised by the pubescent corolla-tube unique in the genus in Europe. Other characters, as life-form, plant height, leaf shape or number of rosettes and stems, chromosome numbers, etc. are very variable in the group (BöCHER et al. 1953, 1955). Taxa in the group are frequently treated as infraspecific taxa of $P$. coronopus, we follow here this treatment.

Plantago coronopus is 3-(5-15)-30 cm high. It develops rich rosettes from its continuously growing taproot (SELL and MURRELL 2009). Leaves are 2-20 $\times 0.1-0.5 \mathrm{~cm}$, linear to lanceolate, dentate, and mostly appressed to the ground. Leaves are fleshy, flat, and usually margin is dentate or lobate, rarely entire [var. weldenii (Rchb.) Pott.-Alap.], glabrous or shortly hairy (Fig. 1). Young rosettes have usually entire, fleshy leaves (Fig. 2). Both subsp. coronopus and subsp.commutata (Guss.) Pilger have high diversity of leaf morphology (MEIKLE 1985). From the middle of rosettes (15-)40-60(-80) 2-25 cm long stems are developed.

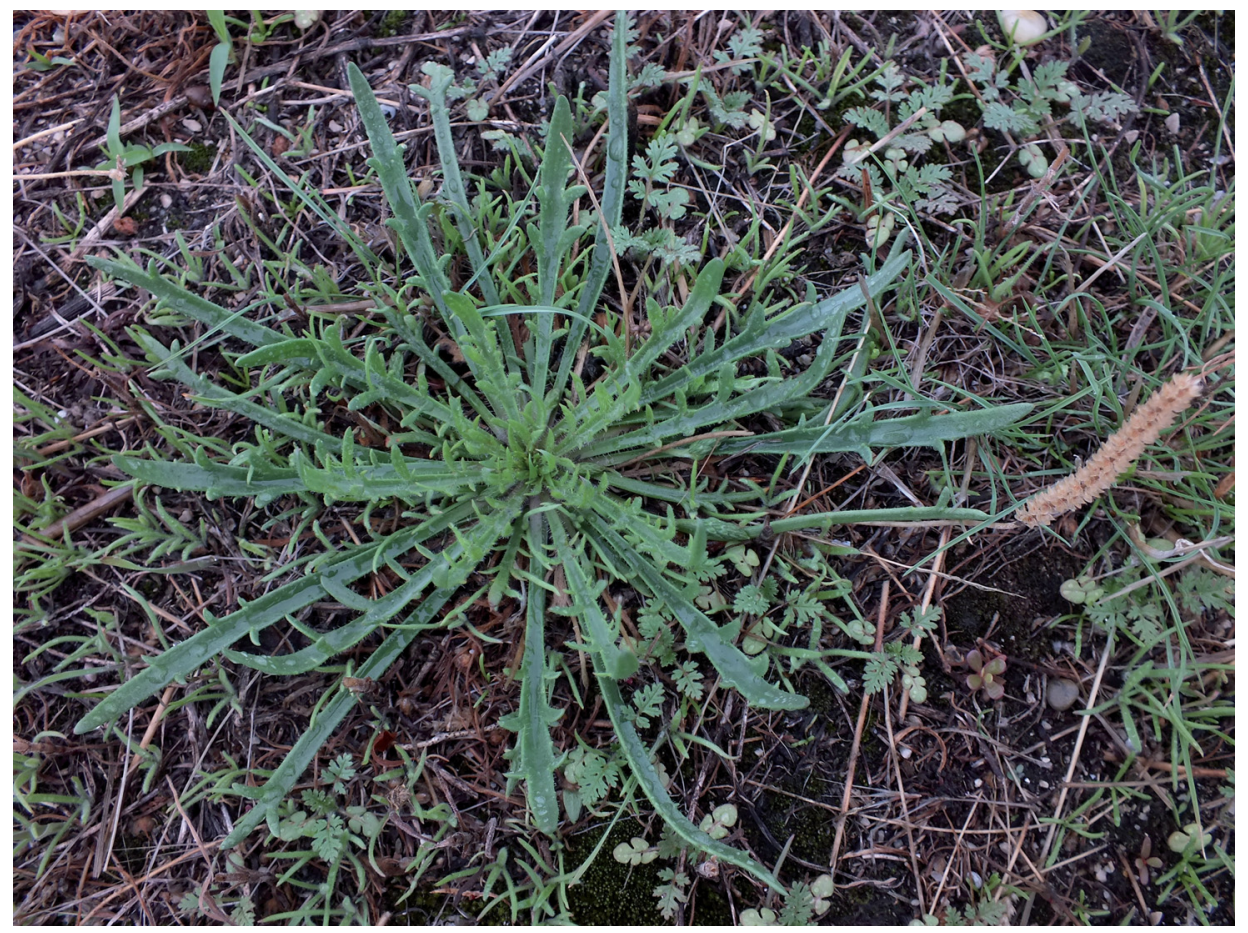

Fig. 1. Rosettes of a young specimen of Plantago coronopus (photo: D. Schmidt, Györ, NW Hungary, 2013). 
Stems are patent, later ascending. Spikes are $1-6 \mathrm{~cm}$ long and $0.3-0.4 \mathrm{~cm}$ wide. Bracts are ovate and subacute or abruptly attenuate into a long apex, shorter than or equal to calyx. Corolla is brown, lobes are oval with apiculate apex, corolla tube is pubescent. There are 4 stamens, filaments are pale, anthers are bright yellow. Capsule is 1.5-2.5 mm locular; seeds are 3-6, 0.8-1 mm long, brown-pink (Chater and Cartier 1976, Sell and Murrell 2009). In Central Europe the annual subsp. commutata occurs, but it can be separated from subsp. coronopus by the stout, thick flower cluster, the bracts are abruptly attenuate with a broad base and long narrow apex and the hyaline spinal of sepal is wider $(0.4-0.6 \mathrm{~mm})$ (Gerst berger 2001). It can be easily distinguished from other Plantago species, which occur in Hungary due to its lobate or pinnatifid leaves. Vegetative rosettes may be confused with juvenile specimens of Scorzonera cana or Plantago lanceolata, which also occur along roadsides.

The native distribution of Plantago coronopus in Europe follows the coastline: it grows on maritime areas of Western and Southern Europe (including the southern part of Scandinavia), on the North African coasts and the islands of Azores, Madeira, and Canary. From the Black Sea region it expands through the Middle East, Caspian region and Central Asia to Afghanistan and Tajikistan

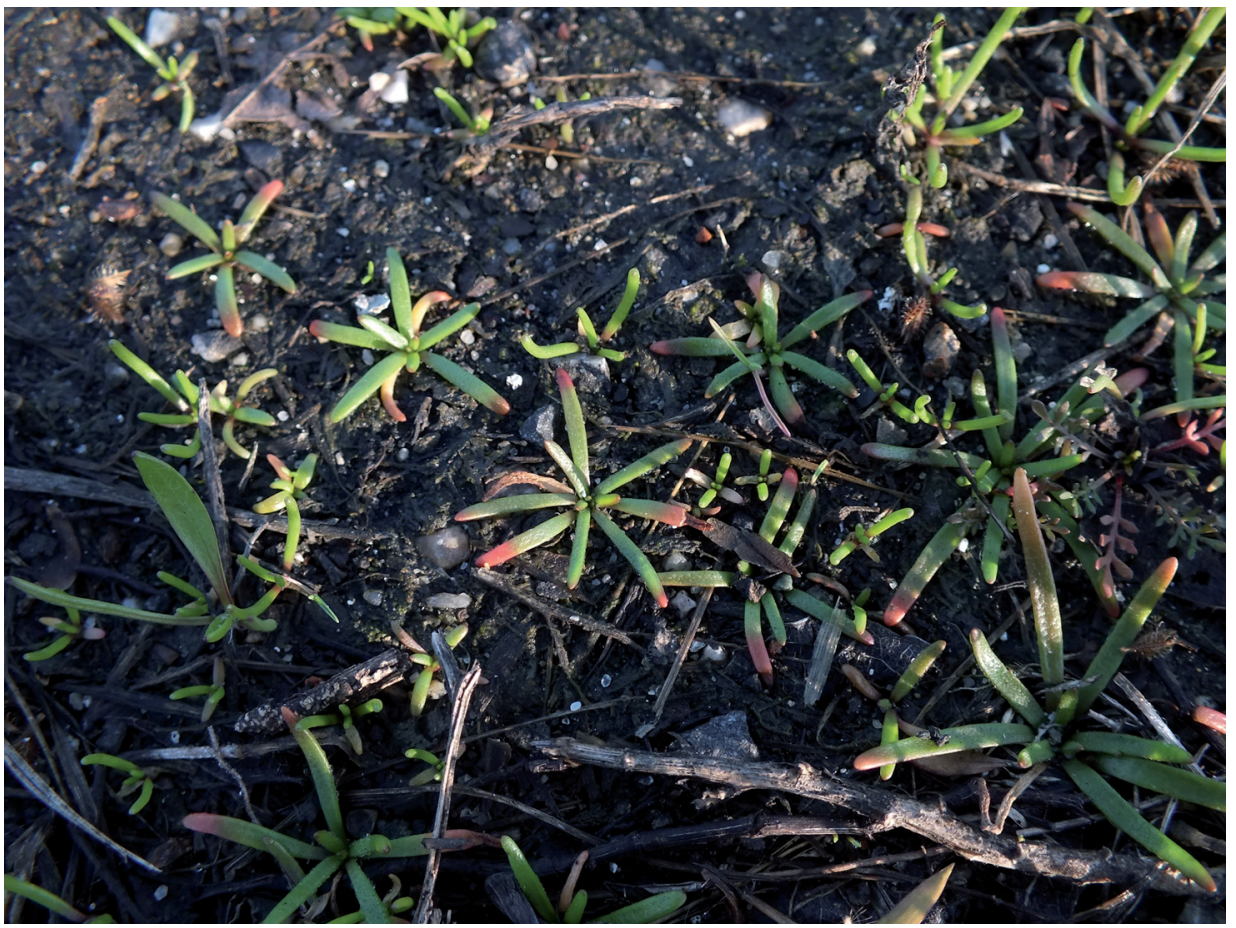

Fig. 2. Seedlings of Plantago coronopus (photo: D. Schmidt, Győr, NW Hungary, 2013). 
(Chater and Cartier 1976, Fedorov 2001, Hegi and Pusch 2009). It is a typical plant of salt-affected sand dunes and rocks. As a naturalised adventive, it occurs sporadically in the eastern states of the United States (DEMPSTER 1993, O'KENNON et al. 1998).

\section{RESULTS}

During a botanical survey in autumn 2013 on the motorways M1 and M70 we have found naturalised stands of Plantago coronopus. Several stands were recorded on a section of motorway M1 between Győr and Komárom exits (86$129 \mathrm{~km}$ ) and on the M70 at Csörnyeföld rest area, $7 \mathrm{~km}$ from the HungarianSlovenian border (SCHMIDT et al. 2014).

In 2014 other sites were recorded, far from the known stands. In the urban area of Csömör near Budapest (Endre Tóth ex litt., and Zoltán Barina ex litt.) and in the Gödöllői-dombság (also near Budapest) one specimen was found by Attila Lengyel (KovÁcs and LENGYEL 2015). One year later we found new stands along the roads of West Hungary (Vas and Györ-Moson-Sopron Counties). Notable expansion was observed along the motorways M70 and M7 of Zala and Somogy Counties by Gergely Király and Michael Hohla (ex litt.). Its explosive spread increased the number of localities to 36 sites in just three years. In 2016, new localities were found along the motorways M3 (Heves County) and M5 (Bács-Kiskun County) and it reached further sections of the motorways M1 and M19.

The occurrences were registered in 30 municipalities in five geographical regions of Hungary. The distance between the westernmost (Fertőszentmiklós) and easternmost known stands (Gyöngyöshalász) is about $300 \mathrm{~km}$. The species occurs on the motorway M7 between Letenye and Balatonkeresztúr on a $65-\mathrm{km}$-long section, on the motorway M1 between Levél and Kisigmánd on a 70-km-long section. The species has appeared in 35 flora mapping quadrant so far (Fig. 3).

\section{Detailed list of localities of Plantago coronopus in Hungary}

The historic data originated from seed sowing (FILARSZKY 1894) are not included.

\section{Alföld (Great Hungarian Plain)}

Duna menti-síkság: Csömör, Auchan hypermarket parking places and HÉV-stop, large stands, 212 m, 8481.3, 28.06.2014; leg. E. Tóth; 08.07.2014, leg. Z. Barina. - Budakalász, Auchan hypermarket, between parking places, several stands, 102 m, 8380.3, 05.10.2016; leg. D. Schmidt. 
Észak-Alföldi-hordalékkúpsíkság: Gyöngyöshalász, M3, Gyöngyös-Adács exit, few specimens, 126 m, 8285.4, 22.06.2016; leg. G. Király.

Duna-Tisza közi sík vidék: Balástya and Csengele, M5 (side Szeged-Budapest), Kistelek-Ópusztaszer exit, rich stand, 88 m, 9585.2, 07.07.2016; leg. D. Schmidt.

\section{Kisalföld (Little Hungarian Plain)}

Győri-medence: Hegyeshalom, at the junction of motorway 101 and M15, homogeneous stands on several hundred metres along the road, $130 \mathrm{~m}, 8069.3$, 07.08.2015; leg. G. Király and R. Diran. - Levél, M1 (side Vienna-Budapest), Moson rest area, few specimens, 120 m, 8169.1, 07.08.2015; leg. G. Király and R. Diran. - Károlyháza, M1 (side Vienna-Budapest), Hanság rest area, few specimens, 114 m, 8269.2, 07.08.2015; leg. G. Király and R. Diran. - Lébény, M1 (side Vienna-Budapest), Lébény exit, few specimens, $114 \mathrm{~m}, 8270.1,03.10 .2016$; leg. D. Schmidt. - Börcs, M1 (side Budapest - Vienna), Börcs rest area, few specimens, 110 m, 8270.4, 03.10.2016; leg. D. Schmidt. - Győr, M1 (side Vienna-Budapest), $0.2 \mathrm{~km}$ from the railway bridge, towards Ikrény overpass, two smaller stands, 116 m, 8371.1, 20.09.2013; leg. D. Schmidt. - Győr, M1 (side Vienna-Budapest), at the railway bridge between Ikrény overpass and Ménfőcsanak-Pápa exit, ca. 20 individuals, 119 m, 8371.1, 20.09.2013; leg. D. Schmidt.

Komárom-Esztergomi-síkság: Győr, M1 (side Vienna-Budapest), Ménfőcsanak-Pápa exit, by the lane going up to the motorway 83 , several microstands, 115 m, 8371.4, 13.09.2013; leg. D. Schmidt. - Győrújbarát, M1 (side ViennaBudapest), Arrabona rest area, by the lane going up to the motorway 82, several micro-stands, 115 m, 8372.3, 13.09.2013; leg. D. Schmidt. - Győrújbarát, M1 (side Vienna-Budapest), Arrabona rest area, road slope between the gas station and the returning road to the motorway, homogeneous stands, $118 \mathrm{~m}, 8372.3,20.09 .2013$; leg. D. Schmidt. - Győrújbarát, M1 (side Budapest-Vienna), Arrabona rest area, on the end of the lane from motorway 82, ca. 50 individuals (only young rosettes), 113 m, 8371.4, 20.10.2013; leg. D. Schmidt. - Töltéstava, M1 (side Vienna-Budapest), Székesfehérvár exit, homogeneous stands, $121 \mathrm{~m}, 8372.3,14.09 .2014$; leg. D. Schmidt. - Győr, M1 (side Vienna-Budapest), Győrszentiván exit, several stands, 138 m, 8372.2, 14.09.2014; leg. D. Schmidt. - Győr, M1 (side Budapest - Vienna), between Győrszentiván exit and Székesfehérvár exit, homogeneous stands, 138 m, 8372.1, 03.10.2016; leg. D. Schmidt. - Bőny, M1 (side Vienna-Budapest), Györ-Kelet exit, on several micro-sites on the edges of the returning road, homogeneous stands, 128 m, 8372.2, 20.09.2013; leg. D. Schmidt. - Ács, M1 (side Vienna-Budapest), Bőny exit, three micro-stands, 118 m, 8373.1, 19.10.2013; leg. D. Schmidt. - Ács, M1 (side Vienna-Budapest), Concó rest area, road slope under 


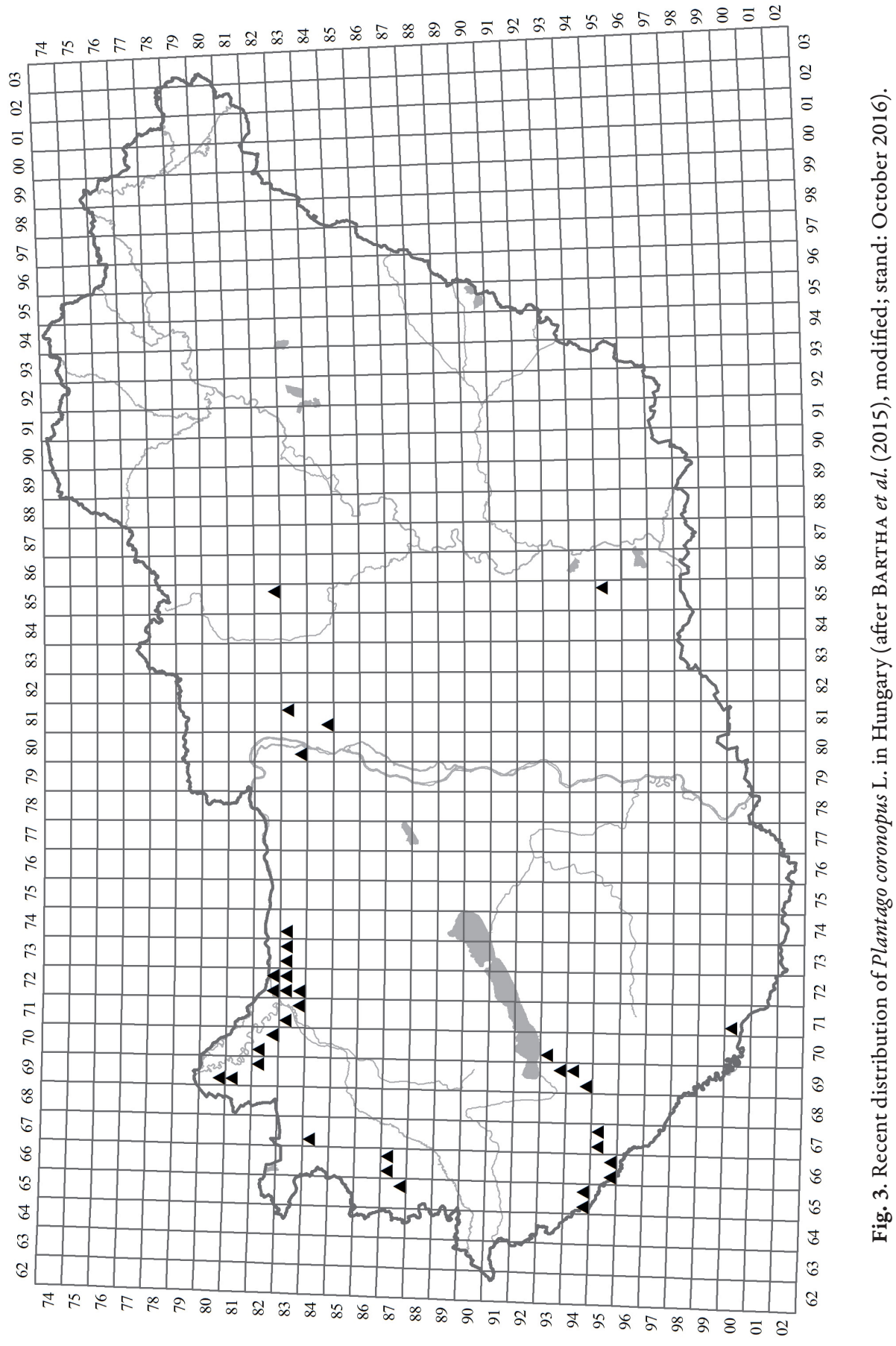


the overpass, homogeneous stands, $121 \mathrm{~m}, 8373.2,19.10 .2013$; leg. D. Schmidt. Ács, M1 (side Vienna-Budapest), Concó rest area, on the end of the lane going to the motorway, small stands (only young rosettes), $120 \mathrm{~m}, 8373.2,19.10 .2013$; leg. D. Schmidt. - Kisigmánd, M1 (side Vienna-Budapest), between kilometre 88 and 90, homogeneous stands on several hundred metres along the road, $125 \mathrm{~m}, 8374.1$, 03.10.2016; leg. D. Schmidt. - Györ, M19, at the lane to Györ, $0.7 \mathrm{~km}$ from GyörKelet exit of the M1, several specimens, $121 \mathrm{~m}, 8372.2,09.20 .2013$; leg. D. Schmidt. - Győr, M19, between Győr-Kelet exit and Győr, several locations, homogeneous stands, $112 \mathrm{~m}, 8272.4$ and 8272.3, 02.09.2016 and 03.10.2016; leg. D. Schmidt.

\section{Nyugat-magyarországi-peremvidék (Western Transdanubia)}

Sopron-Vasi-síkság: Vát, motorway 86 (old), $0.8 \mathrm{~km}$ east from the junction of motorway 88 , road edge, rich stand, $189 \mathrm{~m}$, 08.06.2015; leg. D. Schmidt. - Vát, motorway 88 , road edge by the overpass above the M86, homogeneous stands, 190 m, 11.09.2015; leg. D. Schmidt. - Vassurány, motorway 86, road edge by the overpass above the M86, 2 individuals, $202 \mathrm{~m}$, 03.08.2015; leg. D. Schmidt. - Szombathely, bypass road of the city, $0.14 \mathrm{~km}$ north from Kám turnout, one stand, $201 \mathrm{~m}, 8765.4$, 13.09.2015; leg. D. Schmidt. - Fertőszentmiklós, along the motorway 85 through the town, $0.16 \mathrm{~km}$ east from the junction of Szerdahelyi street, homogeneous stand, $126 \mathrm{~m}, 8467.1,18.06 .2015$; leg. D. Schmidt.

Zalai-dombvidék: Csörnyeföld, M70 towards Letenye, Csörnyeföld rest area, road slope, several individuals, 155 m, 9465.4, 06.10.2013; leg. G. Király and D. Schmidt. - Tornyiszentmiklós, M70, southern side of the border crossing rest area, several individuals, $154 \mathrm{~m}, 9465.3,26.09 .2015$; leg. G. Király and M. Hohla. - Letenye, by the junction of motorway M7 and 7, rich stand, $138 \mathrm{~m}$, 9566.3, 26.09.2015; leg. G. Király and M. Hohla. - Becsehely, M7 (side Zagreb Budapest), Becsehely exit, rich stand, 160 m, 9566.4, 26.09.2015; leg. G. Király and M. Hohla. - Sormás, M7 (side Zagreb - Budapest), Sormás rest area, rich stand, 170 m, 9567.1 and 9567.2, 26.09.2015; leg. G. Király and M. Hohla. Nagykanizsa, by the junction of motorway M7 and motorway 74, several individuals, 140 m, 9567.2, 26.09.2015; leg. G. Király and M. Hohla.

\section{Dunántúli-dombság (Southern Transdanubia)}

Belsö-Somogy: Barcs, on the southern side of the motorway 6, between the railway 60 and Szulok junction, 119 m, 0071.1, 22.06.2015; leg. D. Kovács (KovÁcs and LeNGYel 2015). - Zalakomár, M7 (side Zagreb - Budapest), Zalakomár rest area, several stands, 128 m, 9469.3, 26.09.2015; leg. G. Király and M. Hohla. - Sávoly, M7 exit (side Zagreb-Budapest), several stands, $130 \mathrm{~m}$, 9469.2, 26.09.2015; leg. G. Király and M. Hohla. - Szegerdő, M7 (side Zagreb- 
Budapest), southern side of the Szegerdő rest area, several stands, $111 \mathrm{~m}$, 9369.4, 26.09.2015; leg. G. Király and M. Hohla. - Balatonkeresztúr, M7 (side BudapestZagreb), northern side of the Keresztúr rest area, rich stands, 118 m, 9370.1, 26.09.2015; leg. G. Király and M. Hohla.

\section{Észak-magyarországi-középhegység (North Hungarian Mountains)}

Gödöllői-dombság: Veresegyház, Csomádi road, on the sidewalk edge, one individual, 167 m, 8381.2, 06.09.2014; leg. A. Lengyel (KovÁcs and Lengyel 2015).

\section{Habitat and coenology}

Each observed stand in Hungary is linked to motorways or main roads (often connection to motorways) and also near hypermarkets. The first occurrences near Győr were detected next to the motorway, in Zala County and one population in Győr along the primary national road and in Vas County, Fertőszentmiklós and Csömör the plants were found along the main national road.

The majority of stands appeared directly on the open surfaces next to the edge of the asphalted road. The maximum density of individuals grew 10 to 100 $\mathrm{cm}$ from the shoulder. In this verge zone, dense carpet-like stands were developed which suggests that stony, competition-free surface provides favourable conditions for the species (Fig. 4). These stands consist of hundreds of individuals. Further from the bare stripe zone $(>150 \mathrm{~cm}$ ) in the less disturbed lawn (usually drainage ditches) it grows sporadically, only in one case near Ács, ten metres away from the curb edge in the dense lawn more individuals were found.

The stands generally consist of non-flowering juveniles, first-year specimens with a few flowers and mature rich flowering wintering individuals. The homogeneous stands contain small non-flowering rosettes of the youngest specimens which are considered as the result of the first establishment. Similar colonisation was observed by FrIESE (2011).

According to our observations the ontogenesis of the taxon is quiet longterm, it is germinating almost in the whole year. Its flowering was detected from May until late autumn. Many times the generative phase is also long, new flowering clusters come out next to dry base peduncle. Some individuals were constantly flowering even during the first frosts. Its latest flowering was observed on the 11 th November in 2015, in Szombathely.

Concerning coenological relations, Plantago coronopus was the most dominant species in all 12 relevés which is associated with its strong competition ability. The plant reached the highest cover (85-95\%) on the open bare surface accompanied by Polygonum aviculare agg. and Plantago lanceolata. Ambrosia artemisiifolia, Portulaca oleracea and Taraxacum sect. Ruderalia were accessory spe- 
cies. In total, 45 species were recorded, most of them ruderals without any coenological value. Salt-tolerant species like Atriplex tatarica, Bupleurum tenuissimum, Scorzonera cana, Spergularia media and $S$. salina occurred sporadically with low constancy values. Bupleurum tenuissimum has not been reported yet in secondary habitat along the roads from Hungary.

We determined the following soil properties of Plantago coronopus: in two from the five samples we measured high proportion of skeletons (51-52\%) associated with high content of gravel in the investigated soil layer. Two samples were moderately alkaline $\left(8.0 \mathrm{pH}_{\mathrm{H} 2 \mathrm{O}}\right)$, another two alkaline $\left(8.2 ; 8.6 \mathrm{pH}_{\mathrm{H} 2 \mathrm{O}}\right)$, while one sample reached strong alkaline soil reaction $\left(9.2 \mathrm{pH}_{\mathrm{H} 2 \mathrm{O}}\right)$. In each sample the calcium carbonate content was moderate $\left(8-11 \% \mathrm{CaCO}_{3}\right)$ and the salinity was low $(0.04-0.08 \%)$. The texture was sand or loamy sand, which cannot store the water well and probably originated from the road building. All soils were moderately humic or humic (1.81-3.74 H\%), which improved soil properties for better seed germination and plant development. These results point out that as against the top soil the root zone has already lower salinity.

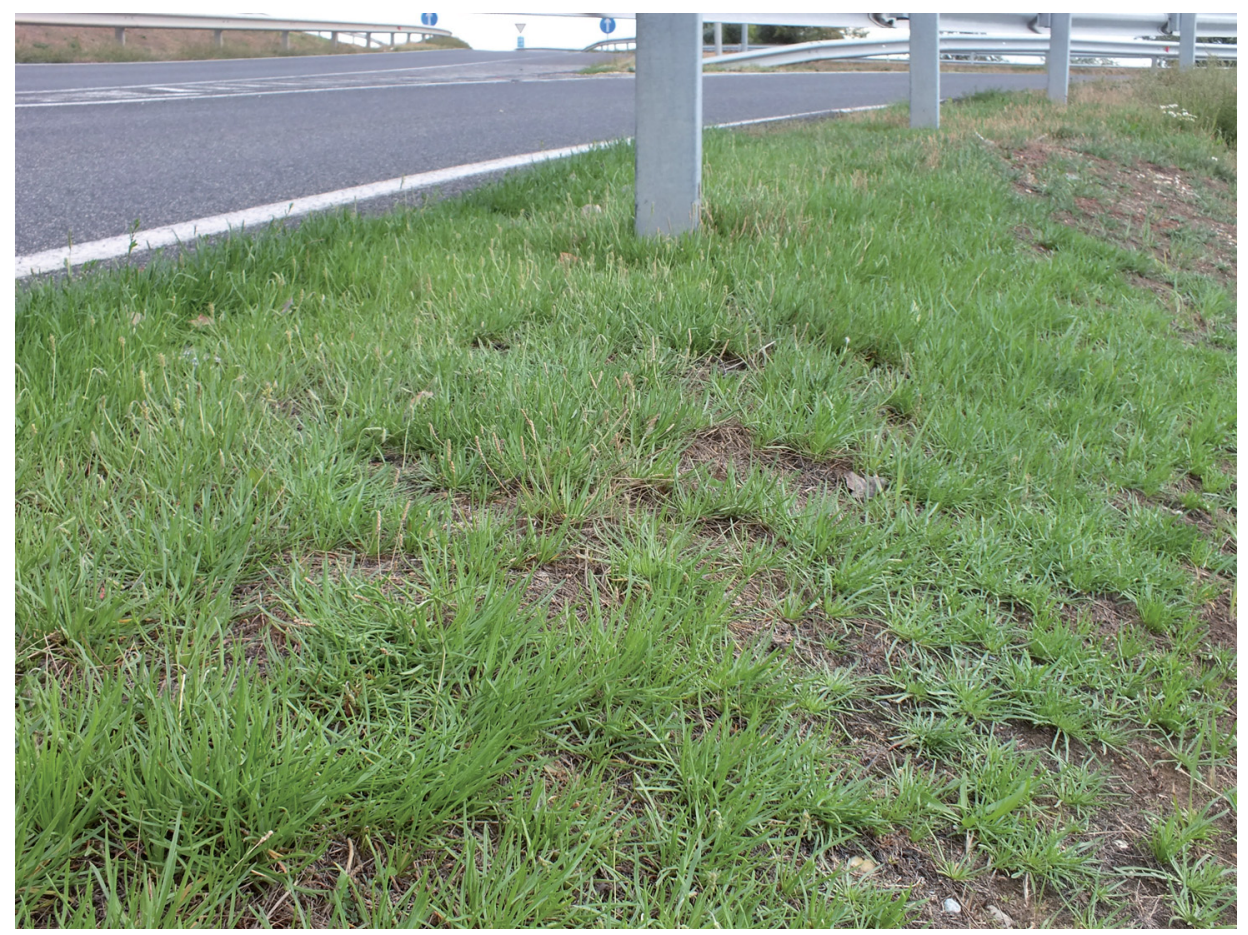

Fig. 4. Homogeneous stand of Plantago coronopus on the motorway M1 next to Arrabona rest area (Győr, NW Hungary) (photo: D. Schmidt 2013). 


\section{DISCUSSION}

The first stands near Györ were found in 2013 on the motorway M1 from Vienna to Budapest direction. This clarifies the eastward introduction from Austria, where it was discovered in 2012 on the A1 motorway (Lower Austria, HoHLA 2012). The rapid establishment of vital stands in distant parts of Hungary highlights its very efficient dispersal. The number of localities has increased up to 35 flora mapping quadrant until now.

Casual introduction of Plantago coronopus to the inland parts of Central Europe (Germany, Switzerland) was detected already in the first half of the 19th century (JANCHEN 1958, Hegi and PusCH 2009). During an intensive research of the German motorways in the 1990s several sites were found (GARVE and Garve 2000, Gerstberger 2001, Breitfeld and Horbach 2006). Friese (2011) reported simultaneous expansion of other salt-tolerant species from coastal areas along the motorway A4 in SE Germany ("Strassenrandhalophyten"), as well as Diewald (2011) who has found these species in similar circumstances in the Bavarian Forest National Park. Slovakia and the Czech Republic have old records of the species from the first half of the 20th century without new observations (MEDVECKÁ et al. 2012, PYŠEK et al. 2012). From Serbia the species has not been reported yet, in Poland it is known only on the Baltic coast (RosLON et al. 2012). In Romania it was published also just from the coastal areas (NEGREAN and Dihoru 2012). Similarly in Slovenia (Jogan 2001, Glas NOvić 2007); however, several specimens were found recently by the roundabout near the border crossing with Hungary (Dolga Vas, D. Schmidt and G. Király, unpublished data). Based on the rapid spread of Plantago coronopus along the German and Austrian motorways (e.g. Diewald 2011, HoHla 2012) the discovery of the Hungarian stands is not surprising. Each road is a part of the European route E60.

Such secondary habitats provide suitable ecological conditions for salttolerant species. Introduction vectors are the vehicles themselves, as their bodywork and fenders spread the stuck propagules in a short time to other remote locations (GERSTBERGER 2001). We observed the same process in the domestic stands. The majority of stands are concentrated on the motorway exits and rest areas, while the largest number of individuals grow on the outer edges of turn lanes, where seeds easily fall from the decelerating vehicles to the ground. The expansion of Plantago coronopus in Hungary and in Central Europe as well is a result of the rapid construction of road network. Continuous development of the motorways especially in Western Transdanubia, increases the potential living space for the species. Therefore we predict a further expansion throughout the country in the following years thanks to the vital stands and rich seed dispersal to greater distances. 
Acknowledgements - The authors thank to Zoltán Barina, Rolf Diran, Michael Hohla, Gergely Király and Endre Tóth for sharing their own data; as well as Zoltán Barina and Gergely Király for providing relevant pieces of literature for the study. Thanks to Viktor Tiborcz for taking part of the translation.

Összefoglaló: Tanulmányunk a Magyarország adventív flórájára nézve új csókalábú útifü (Plantago coronopus L.) térhódítását mutatja be. Az eredetileg Eurázsia tengerparti területein honos sótűrő növény másodlagos terjedésére az 1990-es években figyeltek fel Közép-Európa forgalmas autóútjai mentén. A növény számára kedvező életfeltételeket kínáló autópályák mentén szembetűnően gyors terjedése figyelhető meg, amelynek során a faj 2013-ban megjelent Magyarországon is. Az első előfordulását az M1-es autópálya mellett (Győr) regisztráltuk. Lelőhelyeinek száma rendkívül gyorsan emelkedett, három év alatt 30 település határában, összesen 35 flóratérképezési kvadrátból került elő. Terjedési ütemére jellemző, hogy Magyarország hat nagytája közül ötben már előfordul. A faj terjedését az autópálya-hálózat jelentős bővülése és az autóutak sózása segíti elő. A csókalábú útifü a Magyarországon őshonos útifüfajoktól osztott vagy durván fogas leveleiről könnyen megkülönböztethető.

\section{REFERENCES}

BARINA, Z. (2007): A Vértes és környéke florisztikai kutatásának eredményei I. - Kitaibelia 12(1): $30-40$.

Bartha, D., Király, G., Schmidt, D., Tiborcz, V., Barina, Z., Csiky, J., Jakab, G., Lesku, B., Schmotzer, A., Vidéki, R., Vojt kó, A. and Zólyomi, Sz. (eds): Magyarország edényes növényfajainak elterjedési atlasza. [Distribution atlas of vascular plants of Hungary]. Nyugat-magyarországi Egyetem Kiadó, Sopron, 329 pp.

BAUER, N. (2015): A Limonium gmelinii (Willd.) Kuntze subsp. hungaricum (Klokov) Soó alkalmi megjelenései útpadkákon. - Kitaibelia 20(2): 300. http://dx.doi.org/10.17542/kit.20.300

BöchER, T. W., LARSEN, K. and RAHN, K. (1953): Experimental and cytological studies on plant species I. Kohlrauschia prolifera and Plantago coronopus. - Hereditas 39: 289-304. http://dx.doi.org/10.1111/j.1601-5223.1955.tb03003.x

BöCHER, T. W., LARSEN, K. and RAHN, K. (1955): Experimental and cytological studies on plant species. III. Plantago coronopus and allied species. - Hereditas 41: 423-435. http://dx.doi.org/10.1111/j.1601-5223.1955.tb03003.x

Braun-Blanguet, J. (1928): Pflanzensoziologie. - Springer, Berlin, 330 pp.

Breitfeld, M. and Horbach, H. D. (2006): Plantago coronopus L. jetzt in Oberfranken. - Ber. Bayer. Bot. Gesellsch. 76: 129-134.

Chater, A. and Cartier, D. (1976): Plantago. - In: Tutin, T. G., Heywood, V. H., Burges, N. A., Moore, D. M., Valentine, D. H., Walters, S. M. and Webb, D. A. (eds): Flora Europaea. Vol. 4. Cambridge University Press, Cambridge, pp. 38-44.

СносноloušKovÁ, Z. (2013): Výskyt Spergularia salina podél komunikací udržovaných v zimě solením. - CALLUNA, Čas. západočesk. bot. 18: 10.

Dempster, L. T. (1993): Plantaginaceae. - In: Hickman, J. C. (ed.): The Jepson manual, higher plants of California. University of California Press, Berkeley, pp. 820-821.

Diewald, W. (2011): Plantago coronopus im Bayerischen Wald. - Hoppea 72: 178-179. 
DövéNyI, Z. (ed.) (2010): Magyarország kistájainak katasztere. [Cadastre of small regions of Hungary]. - MTA Földrajztudományi Kutatóintézet, Budapest, 876 pp.

Fedorov, A. (ed.) (2001): Flora of Russia. V. The European part and bordering regions. - CRC Press, Boca Raton, $532 \mathrm{pp}$.

Filarszky, N. (1894): Adatok Budapest flórájához. - Pótf. Term.tud. Közl., pp. 117-121.

FAO (1990): Guidelines for soil description. - Soil Resources, Management and Conservation Service, Land and Water Development Division, FAO, Rome, p. 70.

Friese, M. (2011): Einzug der Halophyten. Florenwandel an der Autobahn A4 im Bautzener Hügelland. - Ber. Naturforsch. Gesellsch. Oberlausitz 19: 79-84.

Garve, E. and Garve, V. (2000): Halophyten an Kalihalden in Deutschland und Frankreich (Elsass). - Tuexenia 20: 375-417.

Gerstberger, P. (2001): Plantago coronopus subsp. commutata als Straßenrandhalophyt eingebürgert in Mitteleuropa. - Tuexenia 21: 249-256.

Glasnović, P. (2007): Prispevek k poznavanju flore Slovenske Istre. - Hladnikia 20: 5-10.

HegI, G. and PUSCH, J. (eds) (2009): Illustrierte Flora von Mitteleuropa 6(1). - Weissdorn-Verlag, Jena, 99 pp.

Hohla, M. and Melzer, H. (2003): Floristisches von den Autobahnen der Bundesländer Salzburg, Oberösterreich, Niederösterreich und Burgenland. - Linzer biol. Beitr. 35(2): 1307-1326.

Hohla, M. and RAABE, U. (2012): Cochlearia danica - das Dänische Löffelkraut - kein überraschender Neuzugang der Flora von Oberösterreich. - Stapfia 97: 206-209.

Hohla, M. (2012): Bromus sitchensis - neu für Österreich, Plantago coronopus - neu für Oberösterreich sowie weitere Beiträge zur Kenntnis der Flora des Innviertels. - Stapfia 97: 180-192.

Janchen, E. (1958): Catalogus Flora Austriae. Teil 1, Heft 3. - Wien, pp. 441-710.

JogAN, N. (ed.) (2001): Gradivo za atlas flore Slovenije. [Materials for the atlas of flora of Slovenia]. - Center za kartografijo favne in flore, Miklavž na Dravskem polju, 443 pp.

Király G. (ed.) (2009): Új magyar füvészkönyv. Magyarország hajtásos növényei. Határozókulcsok. - Aggteleki Nemzeti Park Igazgatóság, Jósvafo, 616 pp.

KirÁLy, G. and Hohla, M. (2015): New stage of the invasion: Sporobolus vaginiflorus (Poaceae) reached Hungary. - Studia bot. hung. 46(2): 205-221. http://dx.doi.org/10.17110/studbot.2015.46.2.149

Medvecká, J., Kliment, J., Májeková, J., Halada, L., Zaliberová, M. and Gojdičová, E. (2012): Inventory of the alien flora of Slovakia. - Preslia 84: 257-309.

MeikLE, R. D. (1985): Flora of Cyprus. Vol. 2. - Bentham-Moxon Trust, Royal Botanic Gardens, Kew, 1969 pp.

MolnáR, V. A. and Löki, V. (2016): Cochlearia danica. In: RAAB-Straube, E. V. and RaUs, T. (eds): Euro+Med-Checklist Notulae 6. - Willdenowia 46(3) (in press).

MSZ-08-0205 (1978): A talaj fizikai és vizgazdálkodási tulajdonságainak vizsgálata. - Magyar Szabványügyi Testület, Budapest, $39 \mathrm{pp}$.

Negrean, G. and Dihoru, G. (2012): Plantago coronopus L. - In: Dihoru, G. and Negrean, G. (eds): Cartea roșie a plantelor vasculare din România. Editura Academiei Române, Bucuresti, p. 407.

Niklfeld, H. (1971): Bericht über die Kartierung der Flora Mitteleuropas. - Taxon 20: 545-571. http://dx.doi.org/10.2307/1218258

O'Kennon, R. J., Diggs, G. M. JR. and Hoggard, R. K. (1998): Plantago coronopus (Plantaginaceae) new to Texas. - Sida 18: 356-358.

par Bailleul, S. M., Coursol, F. and Hay, S. (2006): Flore halophyte des bords de routes. - Flora Quebeca 11: 10. 
Pyšek, P., Danihelka, J., Sádlo, J., Chrtek, J. Jr., Chytrú, M., Jarošík, V., Kaplan, Z., Krahulec, F., Moravcová, L., Pergl, J., Štajerová, K. and TichÝ, L. (2012): Catalogue of alien plants of the Czech Republic (2nd edition): checklist update, taxonomic diversity and invasion patterns. - Preslia 84: 155-255.

RaABE, U. (1990): Das Roggen-Segge (Carex secalina Wahlenbg.) bei Köln. - Floristische Rundbriefe 24: 81-82.

Schmidt, D., Király, G., Horváth, A. and SzŰCs, P. (2014): Autópályán érkező tengerparti jövevény: a Plantago coronopus L. Magyarországon. (Plantago coronopus L. in Hungary: a new adventive species coming from the European seashore). - X. Aktuális Flóra-és Vegetációkutatás a Kárpát-medencében nemzetközi konferencia absztraktkötete, pp. 23-24.

ScotT, N. E. and DAvison, A. W. (1985): The distribution and ecology of coastal species on roadsides. - Vegetatio 62: 433-440. http://dx.doi.org/10.1007/978-94-009-5524-0_48

Sell, P. and Murrell, G. (eds) (2009): Flora of Great Britain 3: Mimosaceae-Lentibulariaceae. Cambridge University Press, Cambridge, $624 \mathrm{pp}$.

ŠERÁ, B. (2010): Road-side herbaceous vegetation: life history groups and habitat preferences. Polish J. Ecol. 58: 69-79.

Soó, R. (1968): A magyar flóra és vegetáció rendszertani-növényföldrajzi kézikönyve III. - Akadémiai Kiadó, Budapest, 264. pp.

Stefanovits, P., Filep, Gy. and Füleky, Gy. (1999): Soil Sciences. - Publishing House of Agriculture, Budapest, $470 \mathrm{pp}$.

ZANGE, R. (1994): Plantago coronopus L. in Hessen. - Bot. Natursch. Hessen 7: 55-60.

(submitted: 08.10.2016, accepted: 15.11.2016)

Appendix 1. Phytocoenological relevés of the habitat of Plantago coronopus.

\begin{tabular}{lccccccccccccc}
\hline Relevé number & 1 & 2 & 3 & 4 & 5 & 6 & 7 & 8 & 9 & 10 & 11 & 12 & Constacy \\
\hline Dominance (\%) & 85 & 80 & 80 & 60 & 60 & 75 & 75 & 95 & 95 & 90 & 70 & 95 & \\
Plantago coronopus & 80 & 70 & 50 & 55 & 55 & 60 & 45 & 93 & 70 & 55 & 20 & 70 & V \\
Polygonum aviculare agg. & 0.1 & 0.5 & 10 & - & - & 1 & 1 & 0.5 & 1 & 2 & 1 & 0.2 & V \\
Plantago lanceolata & 0.2 & 2 & - & - & - & 10 & 3 & 0.5 & 3 & 1 & 1 & 5 & IV \\
Ambrosia artemisiifolia & - & - & - & 0.2 & - & - & 1 & 0.5 & 1 & 20 & - & - & III \\
Portulaca oleracea & 3 & 3 & 2 & - & - & 0.2 & 3 & - & - & - & 20 & 0.5 & III \\
Taraxacum sect. Ruderalia & - & - & 1 & 1 & 1 & 1 & 0.3 & - & - & - & - & - & III \\
Achillea collina & 0.1 & - & - & 0.1 & - & - & - & - & - & - & 1 & - & II \\
Atriplex tatarica & 1 & 1 & - & - & - & - & 5 & - & - & - & 3 & - & II \\
Festuca pseudovina & 0.5 & - & 10 & 1 & - & - & - & - & - & - & 15 & - & II \\
Medicago sativa & 0.1 & 0.3 & - & - & - & - & 0.5 & - & - & - & - & - & II \\
Picris hieracioides & - & - & - & 0.5 & 1 & 0.1 & - & - & - & - & - & - & II \\
Plantago major & - & - & - & 1 & 2 & 0.2 & - & - & - & - & - & - & II \\
Setaria viridis & - & 2 & - & - & - & - & - & 0.5 & 1 & 5 & - & - & II \\
Tragus racemosus & - & - & - & - & - & - & 15 & - & 0.5 & - & 5 & - & II \\
\hline
\end{tabular}


Appendix 1. (continued)

\begin{tabular}{|c|c|c|c|c|c|c|c|c|c|c|c|c|c|}
\hline Relevé number & 1 & 2 & 3 & 4 & 5 & 6 & 7 & 8 & 9 & 10 & 11 & 12 & Constacy \\
\hline Atriplex patula & - & - & - & - & - & - & - & - & - & - & - & 0.1 & I \\
\hline Brassica $\times$ napus & - & - & - & - & - & 0.1 & - & - & - & - & - & - & I \\
\hline Bupleurum tenuissimum & - & - & 0.2 & - & - & - & - & - & - & - & - & - & I \\
\hline Carlina vulgaris & - & - & - & - & - & - & - & - & - & 2 & - & - & I \\
\hline Centaurea jacea agg. & - & - & - & - & - & - & - & - & - & 1 & - & 1 & I \\
\hline Cichoryum intybus & - & - & 1 & 1 & - & - & - & - & - & - & - & 5 & I \\
\hline Convolvulus arvensis & - & - & 0.3 & - & - & 0.1 & - & - & - & - & - & - & I \\
\hline Cynodon dactylon & - & - & - & - & - & - & - & - & 10 & - & - & 10 & I \\
\hline Dactylis glomerata & - & - & - & - & - & - & - & - & - & 3 & - & - & I \\
\hline Digitaria ischaemum & - & - & 0.3 & - & - & - & - & - & - & - & 1 & - & I \\
\hline Digitaria sanguinalis agg. & - & - & - & - & - & - & 1 & - & - & - & 1 & 1 & I \\
\hline Elymus repens & - & - & - & - & - & - & - & - & - & - & - & 1 & I \\
\hline Eragrostis pilosa & - & - & 0.2 & - & 1 & - & - & - & - & - & - & 0.1 & I \\
\hline Erodium cicutarium & - & - & - & - & - & - & - & - & - & - & 1 & - & I \\
\hline Festuca pratensis & - & - & - & - & - & - & - & - & 0.5 & - & - & - & I \\
\hline Kochia scoparia & - & - & - & - & - & - & - & - & - & - & 1 & - & I \\
\hline Lepidium ruderale & - & 0.2 & - & - & - & - & - & - & - & - & - & - & I \\
\hline Linaria vulgaris & - & - & - & - & - & 0.2 & - & - & - & - & - & - & I \\
\hline Lolium perenne & - & - & 5 & - & - & - & - & - & - & - & - & - & I \\
\hline Lotus tenuis & - & - & - & - & - & - & - & - & - & - & - & 0.1 & I \\
\hline Melandrium album & - & - & - & - & - & - & - & - & 1 & - & - & - & I \\
\hline Potentilla argentea & - & 1 & - & - & - & - & - & - & - & - & - & - & I \\
\hline Rumex crispus & - & - & - & - & - & - & - & - & 1 & - & - & - & I \\
\hline Scorzonera cana & - & - & - & - & - & - & 0.2 & - & - & - & - & - & I \\
\hline Setaria pumila & - & - & - & - & - & - & - & - & - & 1 & - & - & I \\
\hline Sonchus arvensis & - & - & - & - & - & - & - & - & 1 & - & - & - & I \\
\hline Spergularia media & - & - & - & - & - & - & - & - & 5 & - & - & - & I \\
\hline Spergularia rubra & - & - & - & - & - & 2 & - & - & - & - & - & - & I \\
\hline Spergularia salina & - & - & - & - & - & - & - & - & - & - & - & 1 & I \\
\hline Trifolium arvense & - & - & - & - & - & 0.1 & - & - & - & - & - & - & I \\
\hline Trifolium campestre & - & - & - & 0.2 & - & - & - & - & - & - & - & - & $\mathrm{I}$ \\
\hline
\end{tabular}

Sample localities (all recorded by D. Schmidt): 1. Győr-Moson-Sopron County, Fertőszentmiklós, $47.590377^{\circ} \mathrm{N}, 16.876207^{\circ} \mathrm{E}, 126 \mathrm{~m}, 11.09 .2015$. - 2. Győr-Moson-Sopron County, Fertőszentmiklós, $47.590609^{\circ} \mathrm{N}, 16.876513^{\circ} \mathrm{E}, 126 \mathrm{~m}, 11.09 .2015$. -3 . Vas County, Vát, $47.286611^{\circ} \mathrm{N}, 16.804004^{\circ}$ 
E, $189 \mathrm{~m}, 11.09 .2015$. 4. Vas County, Vát, $47.286618^{\circ} \mathrm{N}, 16.804326^{\circ} \mathrm{E}, 189 \mathrm{~m}, 11.09 .2015 .-5$. Vas County, Vát, $47.281494^{\circ} \mathrm{N}, 16.803961^{\circ} \mathrm{E}, 190 \mathrm{~m}, 11.09 .2015$. - 6. Vas County, Szombathely, $47.221836^{\circ} \mathrm{N}, 16.658440^{\circ} \mathrm{E}, 201 \mathrm{~m}, 13.09 .2015$. - 7. Győr-Moson-Sopron County, Győr, 47.647727 $\mathrm{N}, 17.712715^{\circ} \mathrm{E}, 121 \mathrm{~m}, 14.09 .2015$. - 8. Győr-Moson-Sopron County, Győrújbarát, 47.632590 N, 17.666624 ${ }^{\circ}$ E, 115 m, 14.09.2015. - 9. Győr-Moson-Sopron County, Győrújbarát, 47.632539 $\mathrm{N}, 17.667118^{\circ} \mathrm{E}, 118 \mathrm{~m}, 14.09 .2015$. - 10. Győr-Moson-Sopron County, Győrújbarát, $47.632937^{\circ}$ $\mathrm{N}, 17.660616^{\circ} \mathrm{E}, 113 \mathrm{~m}, 14.09 .2015$. - 11. Györ-Moson-Sopron County, Györ, 47.644323 $\mathrm{N}$, $17.615045^{\circ} \mathrm{E}, 113 \mathrm{~m}, 14.09 .2015$. 12. Győr-Moson-Sopron County, Győrújbarát, $47.634578^{\circ} \mathrm{N}$, $17.661839^{\circ} \mathrm{E}, 113 \mathrm{~m}, 14.09 .2015$. 